\title{
REVITALISASI NILAI-NILAI SOSIAL TAUHID DALAM MERESPONS REALITAS KEKINIAN
}

\author{
Ahmad Zainuddin \\ Institut Keislaman Abdullah Faqih Gresik, Indonesia \\ E-mail: zain.nanta@gmail.com
}

\begin{abstract}
This article discusses the efforts to revitalize social values on the basis of faith in monotheism that is alienated from social reality. So far, Islamic movement is too normative and tends to neglect differentiation, segmentation and social stratification in society. Consequently, the normative sentiments regarding the unity of the people became much more prominent than the actual commitment to defend the weak, displaced and oppressed groups in society. To understand Islam needs to look at the historical determinism, in order to avoid a partial understanding. Pure and social ritual can be performed equally an ideal personification of a true Muslim. The egalitarian character of Islam as a religion of liberation manifestation should be used to understand human conception and reality. Thus, someone will not be separated from his nature as human being who must worship the Lord and carry out social functions, as well as to avoid the trap of ritual extremism or social extremism. The revitalization of social values of monotheism by integrating relational networks of Islam in social change gave birth to anti ethnocentrism, universalism and liberation.
\end{abstract}

Keywords: Social values; social reality; monotheism.

\section{Pendahuluan}

Selama ini gerakan Islam terlalu bersifat normatif dan cenderung Formatted: No abai terhadap diferensiasi, segmentasi dan stratifikasi sosial yang terjadi dalam masyarakat. Akibatnya, sentimen normatif mengenai persatuan dan kesatuan umat menjadi jauh lebih menonjol daripada komitmen membela kelompok-kelompok yang lemah, tergusur dan tertindas di dalam masyarakat. 
Lantas, apakah agama bisa menjadi sumber kekuatan dan inspirasi ideologis untuk melakukan oposisi dan revolusi ${ }^{1}$ terhadap kekuatan elite yang hegemonik? Bagi Antonio Gramsci, fungsi agama salah satunya adalah memberikan bentuk-bentuk kesadaran baru yang sesuai dengan tahap-tahap perkembangan sosial yang baru. Menurutnya, sesuatu yang memiliki nilai penting khusus adalah agama atau ideologi yang bisa mewujudkan suatu kehendak kolektif nasionalpopuler seperti yang ia lihat pada protestanisme dalam revolusi Perancis. $^{2}$

Saat ini wacana agama dan perubahan sosial menjadi penggalan pendek sejarah peradaban. Hubungan tersebut dibangun dari rumusan pertanyaan dan ragam argumentasi mengenai letak agama dalam perubahan sosial. Merujuk pada Max Weber (1864-1920), bahwa agama yang berjasa melahirkan perubahan sosial paling spektakuler dalam sejarah peradaban manusia. Dengan nilai-nilai keagamaan, penganutnya terdorong melakukan perubahan sosial dalam rangka melahirkan peradaban yang lebih humanis. Dalam bukunya Etikea Protestan dan Semangat Kapitalisme, Weber mengemukakan aspek-aspek tertentu dalam etika Protestan yang merupakan perangsang kuat dalam meningkatkan pertumbuhan ekonomi kapitalis dalam tahaptahap pembentukannya. ${ }^{3}$

\footnotetext{
1 Wacana revolusi yang dimaksud penulis bukanlah perubahan radikal yang menggunakan kekerasan dan perjuangan berdarah. Revolusi di sini lebih menunjuk pada radikalisme proses sadar diri. Makna dari itu, revolusi di sini adalah tahapan moral yang setiap orang secara individu berani sadar pada otonominya. Model revolusi ini memiliki dua dimensi. Pertama, dimensi individual yang tiap-tiap orang melakukan proses eksistensi diri tidak hanya dengan mendidik diri hingga tercerakan budinya, tetapi terpupuk pula intuisi akal sehatnya untuk menolak setiap irasionalitas yang membelenggu. Kedua, dimensi sosial yang kesadaran individu berkembang menjadi kesadaran sosial. Kesadaran bersama ini terus berkembang menjadi kesadaran untuk memperjuangkan kepentingan pemerdekaan. Implementasi kesadaran sosial yang sudah tercerahkan akan meminta wujud perubahan berupa sistem negara hukum yang berprinsip keadilan dan pemerataan kesejahteraan. Lihat Mudji Sutrisno, "Revolusi Akal Sehat" dalam Frans M. Parera dan T. Jakob Koekerits (eds.), Masyarakat Versus Negara: Paradigma Baru Membatasi Dominasi Negara (Jakarta: Kompas, 2002), 318-320.

2 Pernyataan Antonio Gramsci dikutip dari Robert N. Bellah dan Phillip E. Hammond, Varieties of Civil Religion: Beragam Bentuk. Agama Sipil dalam Beragam Bentuk. Kekuasaan Politik, Kultural, Ekonomi, dan Soaial, terj. Imam Khoiri (Yogyakarta: Ircisod, 2003), 144.

${ }^{3}$ Ishomudin, Pengantar Sosiologi (Jakarta: Ghalia Indonesia, 2002), 57.
} 
Demikan juga saat Islam hadir di Jazirah Arab pada abad ketujuh masehi, di mana Muhammad yang hadir sebagai pemimpin baru di Mekkah, selain mengemban misi ketauhidan, ia juga melakukan perubahan dari era kebodohan menjadi era Islam yang menjunjung tinggi pilar-pilar keadilan dan kemaslahatan. Ajaran Islam membawa pesan tentang hak-hak orang miskin, melindungi perempuan dan membela hak-hak budak yang tertindas. Bahkan setelah Muhammad hijrah ke Madinah, ia mampu membentuk masyarakat Madani dengan tatanan masyarakat baru lintas suku dan kabilah dalam suatu negara yang dibangun atas dasar kebersamaan dan keadilan. ${ }^{4}$

Kebangkitan Islam yang menjadi harapan dan agenda umat Islam sedikitnya dilatarbelakangi oleh tiga hal: Pertama, kerinduan mendalam akan "warisan kejayaan Islam" (the legacy of Islam) masa lalu, di mana Islam mendominasi dunia selama tujuh abad di berbagai bidang. Kedua, adanya hegemoni Barat dalam percaturan internasional serta intimidasi mereka terhadap dunia Islam dengan kolonialisme dan imperialismenya yang kemudian mengeksploitasi sumber daya alam dan melumpuhkan sumber daya manusianya, dan ketiga, keterbelakangan umat Islam di berbagai bidang dan posisi mereka sebagai "umat pinggiran". 5

Setelah sekian dekade dalam bayang-bayang romantisme kejayaan masa lalu, kini umat Islam dihadapkan pada realitas faktual tentang kemiskinan, ketertindasan dan keterbelakangan yang menjadi ancaman umat Islam. Selama ini gerakan Islam terlalu bersifat normatif dan cenderung mengabaikan adanya diferensiasi, segmentasi dan stratifikasi sosial yang terjadi dalam masyarakat. Sebagai akibatnya, sentimen normatif mengenai persatuan dan kesatuan umat menjadi jauh lebih menonjol daripada komitmennya yang aktual untuk membela kelompok-kelompok yang lemah, tergusur dan tertindas di dalam masyarakat. Konsep-konsep objektif al-Qur'ân mengenai du 'afâ' dan mustad'afîn yang diartikan sebagai kelompok yang lemah dan tertindas secara ekonomi dan politik hanya dipahami pada tataran konsep yang normatif daripada dielaborasi secara empiris.

Bagi intelektual Muslim kontemporer yang terdidik dalam dialektika pemikiran rasional, tidak mungkin dapat meninggalkan begitu saja kesenjangan antara ajaran agama dengan realitas. Sulit

${ }^{4}$ Nourouzzaman Shiddiqi, Jeram-jeram Perdaban Islam (Yogyakarta: Pustaka Pelajar, 1996), 94-95.

5 Asep Syamsul M. Romli, Isu-isu Dunia Islam (Yogyakarta: Dinamika, 1996), 38-40. 
untuk merekonsiliasi, misalnya firman Tuhan "Engkau adalah ummah yang terbaik yang dilahirkan untuk manusia" dengan realitas di mana sebagian dari ummab ini terdiri dari orang-orang yang tertindas (underdog) oleh tatanan dunia feodal. ${ }^{7}$

Di antara kepentingan Islam sebagai sebuah ideologi sosial adalah bagaimana Islam dapat mengubah masyarakat sesuai dengan cita dan visinya mengenai transformasi sosial yang berujung pada terjadinya perubahan sosial di tengah masyarakat Islam. Kini, secara kebetulan umat Islam di Indonesia adalah penduduk mayoritas, karenanya implementasi sikap hidup Tawhî̉ di era kontemporer ini sangat dituntut menyehatkan sistem dan memberdayakan rakyat di berbagai aspek kehidupan, baik di bidang politik, ekonomi, budaya, dan aspekaspek kehidupan penting lainnya. Lebih-lebih ketika komunitas Muslim memiliki posisi dan otoritas formal yang penting serta menentukan kepentingan hidup orang banyak. Umat Islam secara kolektif dan individu diharapkan menjadi teladan terbaik dalam mempraktikkan kehidupan dan membentuk komunitas sosial yang saleh. Inilah yang dikehendaki dalam wacana dan perspektif tauhid sosial. Dalam aktualisasi konkretnya, tuntutan untuk mengaktualisasikan tauhid dalam kehidupan sosial tidak sederhana karena akan bersinggungan dengan ragam kepentingan yang melekat dalam diri manusia selaku aktor dan sistem. ${ }^{8}$

Artikel ini mencoba menganalisis perlunya merevitalisasi nilai-nilai sosial tauhid dalam merespons realitas kekinian, karena nilai-nilai sosial ketauhidan Muslim telah lama teraleniasi karena iklim politik yang tidak menyejahterakan bagi masyarakat. Revitalisasi di sini dapat diartikan sebagai upaya menyemarakkan kembali semangat atau daya hidup (vitality) setelah mengalami masa-masa kemunduran atau kemerosotan sebelumnya. ${ }^{9}$ Di sini penulis akan mengangkat pemikiran Ali Syariati dan Ḥasan Ḥanafí sebagai pilar utama dalam diskursus sosialisme Islam. Syariati adalah sosok intelektual Muslim

\footnotetext{
${ }^{6}$ Q.S. Âl 'Imrân [3]: 110.

7 Bassam Tibi, Islam, Kebudayaan dan Perubahan Sosial, terj. Misbah ZE dan Zainul Abbas (Yogyakarta: Tiara Wacana, 1999), 52.

${ }^{8}$ M. Amin Rais, Cakrawala Islam: Antara Cita dan Fakta (Bandung: Mizan, 1997), 1314.

${ }^{9}$ Revitalisasi merupakan kata serapan dari bahasa Inggris revitalization, akar katanya revitalize. Dalam Webster New Dictionary $3^{\text {rd }}$ College Edition (1988), disebutkan revitalize berarti to bring vitality, vigor, back to after a decline, yang maksudnya sebagaimana penjelasan dalam kutipan.
} 
yang revolusioner. Pandangan dunia Syariati yang paling menonjol adalah menyangkut pemikiran tentang hubungan antara agama dan politik, yang dapat dikatakan menjadi dasar dari ideologi pergerakannya. ${ }^{10}$ Syariati menawarkan tauhid sebagai basis revolusi transenden dengan fondasi teologi Islam progresif, protestanisme Islam, dan intelektual tercerahkan. Sementara itu, Hasan Hanafí senafas dengan Syariati dalam memberdayakan Islam sebagai kekuatan revolusi. Untuk mewujudkan itu, Hanafî menawarkan pertama, transformasi teologi dari teosentris menjadi antroposentris. Kedua, untuk membangun teologi antroposentris digunakan metode dialektika, hermeneutika, fenomenologi, dan metode eklektik. Ketiga, membangun nalar teologi kritis dan rasional dengan tidak meninggalkan akar tradisi Islam.

\section{Ali Syari'ati Protestantisme Islam Melahirkan Rausyan Fikr}

Ali Syariati (1933-1977) adalah seorang intelektual, ideolog dan pemikir revolusioner Iran. Kajian Syariati mengarah pada tema-tema Islam dan sosiologi dalam bentuknya yang khas. Ia melakukan kajiannya dengan memadukan sosiologi dengan hasil pemikiran orisinilnya. Hal ini disebabkan Syariati tidak puas dengan apa yang diberikan oleh pandangan positivistik bahwa sosiologi hanya sematamata sebagai ilmu. Syariati tidak hanya seorang intelektual Muslim yang revolusioner, ia juga aktivis pergerakan yang senantiasa berada di tengah-tengah massa rakyat Iran. Yang menjadi dasar dari iedologi pergerakan Syariati adalah pandangannya menyangkut hubungan antara agama dan politik.

Pandangan Islam Syariati yang progresif dan revolusioner bersumber pada satu sistem keyakinan, tauhid. Dalam hal ini, tauhid adalah pandangan dunia (worldview) mistis-filosofis yang melihat jagad raya sebagai organisme hidup tanpa dikotomisasi. Semua adalah kesatuan (unity) dalam trinitas antara Tuhan, manusia, dan alam. Baginya, tauhid menyatakan bahwa alam adalah sebuah totalitas kreasi harmoni. Tanggungjawab seorang Muslim adalah untuk mengenali dan menerima tuntutan realitas dan menggerakkannya secara masif:

My worldview consist of tawhîd. Tawhîd in the sense of oneness of God is of course accepted by all monotheist. But tawhîd as a world-view in the

10 Azyumardi Azra, Pergolakan Politik Islam: Dari Fundamentalisme, Modernisme, bingga Post-Modernisme (Jakarta: Paramadina, 1996), 70. 
sense I intend in my theory means regarding the whole universe as a unity. $^{11}$

Jika tauhid dalam pandangan Syariati adalah kesatuan antara Tuhan, manusia, dan alam semesta, maka kondisi masyarakat yang penuh diskriminasi sosial, ketidakadilan, dan kesewenang-wenangan dapat dikategorikan sebagai syirik, lawan dari tauhid. Dalam masyarakat Islam yang bertauhid, terdapat kesatuan utuh yang bukan merupakan konstruk hukum:

All buman being not same solely: they are brother. Difference between equation and brotherhood is clear. Equation is concept punish, whereas brotherhood express the uniformity of essence and character of all human being; all buman being come from one single source, any their busk colour. Both men and woman are same... men And woman created from same substansi materials and, at the time of same, by same creator. ${ }^{12}$

Tauhid memandang dunia sebagai suatu imperium. Sedangkan lawannya syirik memandang dunia sebagai sistem feodal. Dengan pandangan ini, maka dunia memiliki kehendak, kesadaran diri, tanggap, cita-cita, dan tujuan. Dengan bersandar pada keyakinan ini, Syariati menolak politeisme, dualisme, dan trinitarianisme. Ia hanya percaya pada tauhid, monoteisme. Monoteisme menegasikan segala pengakuan dan keyakinan mausia atas tuhan-tuhan palsu. Jika pada zaman jahiliyyah, tuhan-tuhan palsu itu dimanifestasikan dalam wujud berhala-berhala, maka pada zaman modern ini-menurut Syariatituhan-tuhan palsu itu mewujud dalam banyak aspek dan bidang yang kompleks dari sekadar berhala-berhala sesembahan. Tuhan-tuhan itu lebih berbentuk sistem tirani yang sarat dengan penindasan, atau kemegahan dunia yang ketika meraihnya harus merampas hak-hak orang lain. $^{13}$

Generalisasi naif Syariati menjadi ajakan politik yang bersifat menggembleng, untuk menolak, menentang dan melawan segenap sumber kekuatan syirik, seperti kediktatoran, sistem kapitalis dan ulama resmi. Ia juga bermaksud menyebut Muslim sebagai satusatunya agen sosial yang dapat melahirkan kesempatan historis dan revolusioner seperti ini, karena sebagai ahli tauhid, mereka tidak mungkin hidup damai dengan kesyirikan. Pandangan dunia syirik didasarkan pada, dan berkembang berkat, kontradiksi. Sebagai

\footnotetext{
11 Ali Syari'ati, On the Sociology of Islam (Bandung: Mizan Press, 1979), 82.

12 Ibid., 77.

13 Ali Syari'ati, Makna Haji (Jakarta: Yayasan Fatimah, 2002), 232.
} 
pandangan dunia, tujuan tauhid adalah menghapus kontradiksi. Ini merupakan ajakan untuk "bangkit melawan" segala tuhan palsu. ${ }^{14}$

Dalam pandangan hidup tauhid, tidak ada kontradiksi antara manusia dengan alam, ruh dengan badan, dunia dengan akherat, dan antara spirit dengan materi. Dengan demikian tauhid menegasikan segala bentuk kontradiksi legal, sosial, politik, rasial, nasional, teritorial, maupun genetik. Sebaliknya, segala pertentangan yang muncul di dunia adalah disebabkan oleh pandangan hidup syirik, yang ditandai dengan diskriminasi rasial dan kelas. Konsekuensi pandangan hidup tauhid adalah menolak ketergantungan manusia terhadap kekuatan sosial tertentu, tetapi mengaitkan manusia dengan kesadaran pada kehendak Tuhan.

Dalam kondisi keterpurukan masyarakat, Syariati berpikir Islam harus mampu menjadi penggerak kesadaran masyarakat. Islam perlu lebih dipahami sebagai sebuah pandangan dunia komprehensif; sebuah rencana untuk merealisir potensi manusia sepenuhnya, baik secara perseorangan maupun kolektif, untuk tujuan makhluk secara keseluruhan. Di sinilah letaknya bahwa Islam berfungsi sebagai ideologi pembebasan.

Syariati berupaya menegaskan perbedaan Islam dengan pemahaman umum tentang agama yang dikonsepsikan oleh Emile Durkheim. Dalam bentuk yang tidak ideologis, agama seperti dikemukakan Durkheim sebagai "suatu kumpulan keyakinan warisan nenek moyang dan perasaan-perasaan pribadi; peniru terhadap modus-modus, agama-agama, ritual-ritual, aturan-aturan, konvensikonvensi dan praktik-praktik yang secara sosial telah mutawâtir selama generasi demi generasi. Ia tidak harus merupakan menifestasi dari semangat ideal kemanusiaan yang sejati". ${ }^{15}$ Jika Islam diubah bentuknya dari "mazhab ideologi" menjadi sekadar "pengetahuan kultural" dan sekumpulan pengetahuan agama sebagaimana yang dikonsepsikan Durkheim, ia akan kehilangan daya dan kekuatannya untuk melakukan gerakan, komitmen, dan tanggung jawab, serta kesadaran sosial sehingga ia tidak memberi kontribusi apa pun kepada masyarakat.

Untuk mencapai tujuan menggerakkan masyarakat melalui ideologisasi Islam, Syariati menempuh beberapa langkah strategis. Ia

\footnotetext{
14 Ibid., 299.

15 Ali Syari'ati, Ideologi Kaum Intelektual: Suatu Wawasan Islam, terj. Syafiq Basri dan Haidar Bagir (Bandung: Mizan, 1994), 81.
} 
berupaya meredefinisi Islam dengan menyajikan tahapan-tahapan ideologi secara detail berkenaan dengan cara memahami Tuhan, mengevaluasi segala sesuatu yang berhubungan dengan ide-ide yang membentuk lingkungan sosial dan mental kognitif masyarakat, serta metode atau usulan-usulan praktis untuk mengubah status quo yang tidak memuaskan kehendak masyarakat. ${ }^{16}$

Pada tahap pertama, Syariati meletakkan pandangan dunia tauhid sebagai pandangan dasar. Pendangan ini menyatakan secara langsung bahwa kehidupan merupakan bentuk tunggal, organisme yang hidup dan sadar, memiliki kehendak, perasaan, dan tujuan. Hal demikian berbeda dengan pandangan dunia yang membagi kehidupan dalam kategori yang berpasangan: dunia dan alam kekal; fisik dan gaib; substansi dan arti; rohani dan jasmani. ${ }^{17}$ Karena itu diskriminasi manusia atas dasar ras, kelas, darah, kekayaan, kekuatan dan lainnya tidak bisa dibiarkan, karena ia dianggap berlawanan dengan nilai-nilai Ketuhanan.

Pada tahap kedua adalah berkenaan dengan bagaimana memahami dan mengevaluasi pemikiran dan segala sesuatu yang membentuk lingkungan sosial dan mental. Bagi Syariati, Islam adalah pandangan dunia yang bisa dipahami dengan mempelajari al-Qur'ân sebagai kumpulan ide-ide dan mempelajari sejarah Islam sebagai ringkasan kemajuan yang pernah dialami dari permulaan misi Nabi sampai pada dunia kontemporer. ${ }^{18}$

Dengan berpijak pada al-Qur'ân, Syariati melihat keseluruhan sejarah sebagai sebuah konflik kekuatan-kekuatan, sementara itu manusia sendiri menjadi medan perang antara asal jasmaninya yang rendah dan semangat Ketuhanannya. Dialektika sejarah seperti ini sangat mudah diidentifikasi meminjam konsep dialektika sejarah Marxis, meskipun tidak secara keseluruhan. ${ }^{19}$ Meski demikian, Syariati mengklaim bahwa analisisnya mengenai dialektika Qabil dan Habil

16 Ali Syari'ati, Tugas Cendekiawan Muslim, terj. M. Amien Rais (Jakarta: Srigunting, Cet. 2, 2001), 160.

${ }^{17}$ Syari'ati, On the Sociology, 82.

${ }^{18}$ Ibid., 83.

19 Menurut Marx, yang menentukan perubahan dan perkembangan masyarakat adalah pertentangan antara kelas-kelas sosial atau terjadinya kontradiksi dalam masyarakat, dan kelas-kelas sosial merupakan aktor sejarah utama. Jadi yang menentukan jalannya sejarah bukan individu-individu tertentu, melainkan kelaskelas sosial yang masing-masing memperjuangkan kepentingannya. Lihat Franz Magnis-Suseno, Pemikiran Karl Marx: Dari Sosialisme Utopis ke Perselisiban Revisionisme (Jakarta: Gramedia Pustaka Utama, 2000), 125. 
sebagai sebuah simbol pertentangan yang terus-menerus adalah pemikiran orisinil dalam konteks pemahaman Islam dari intisari beberapa ayat dalam al-Qur'ân.

Pada tahap berikutnya, diperlukan suatu ikhtiar bagaimana mencari dan menerapkan jalan praktis untuk menumbangkan status quo. Caranya adalah melengkapi masyarakat dengan tujuan dan citacita yang diinginkan, langkah-langkah praktis berdasarkan kondisi masyarakat, serta upaya menciptakan perubahan dan kemajuan dalam aksi-aksi revolusioner. Ideologi harus mengejawantah sebagai suatu amanat yang sedang dihidupkan kembali untuk membangkitkan kaum yang menderita, bodoh dan lamban, agar bangun dan menegaskan hak-hak serta identitasnya.

Syariati memandang sejarah sebagai konstruksi pola dasar (archetral) dari berbagai realitas unik, yang muncul dalam fakta-fakta sejarah, untuk diarahkan agar mencapai tujuan ideologis tertentu, dengan kata lain, fakta-fakta sejarah yang akan membisu jika dibiarkan begitu saja, harus direkonstruksi secara revolusioner.

Jika Arnold Toynbee, misalnya, pernah mengatakan bahwa sejarah bergerak dalam kesinambungan "seragam dan pertahanan", 20 Syariati dalam hal ini lebih menambahkan bahwa suatu pergerakan agama (Islam) harus dijaga agar tetap dalam modus agresifnya melalui interpretasi aktif atas kandungan aktualnya ketimbang pada manifestasi lahiriahnya.

Keseluruhan langkah yang dikonstruksi Syariati pada intinya akan mengerucut pada satu tujuan, yaitu pembaruan Islam (protestanism). Ia menegaskan:

To emancipate and guide the people, to give birth to a new love, faith, and dynamism, and to shed light on people's hearts and minds and make them aware of various elements of ignorance, superstition, cruelty and degeneration in contemporary Islamic societies, an enlightened person should start with "religion". By that I mean our peculiar religious culture and not the one predominant today. He should begin by an Islamic Protestantism similar to that of Christianity in the Middle Ages, destroying all the degenerating factors which, in the name of Islam, have stymied and stupefied the process of thinking and the fate of the society, and giving birth to new thoughts and new movements. Unlike Christian

20 Arnold Toynbee dan Daesaku Ikeda, Perjuangkan Hidup: Sebuab Dialog, terj. Iskandar (Jakarta: PT. Internusa, 1987), 294. 
Protestantism, which was empty-handed and had to justify its liberationist presentation of Jesus, Islamic Protestantism has various sources and elements to draw from. ${ }^{21}$

Menurut Syariati, gerakan Protestanisme Islam akan mengeluarkan energi sangat besar dan memungkinkan seorang Muslim yang tercerahkan untuk:

1 Menyaring sumber-sumber daya masyarakat Islam dan mengubah penyebab kebobrokan dan kemandekan menjadi kekuatan dan gerakan.

2 Mengubah konflik antarkelas dan sosial yang ada menjadi kesadaran akan tanggung jawab sosial.

3 Menjembatani kesenjangan yang semakin lebar antara pulau yang dibuni oleh orang yang tercerabkan dengan pantai rakyat kebanyakan dengan menjalin hubungan kekeluargaan dan pemahaman mereka, dan menempatkan agama untuk kepentingan rakyat.

4 Mencegah agar senjata agama tidak jatuh kepada mereka yang tidak patut memilikinya. Tujuannya adalah memanfaatkan agama untuk tujuan-tujuan pribadi yang dengan cara itu memperoleh energi yang diperlukan untuk menggerakkan rakyat.

5 Mengusahakan suatu kebangkitan kembali agama yang-dengan kembali kepada agama yang hidup, dinamis, kuat dan adil untuk melumpuhkan agen-agen reaksioner dalam masyarakat, sekaligus menyelamatkan rakyat dari unsur-unsur yang membius mereka.

6 Menghilangkan peniruan dan kepatuhan dan menggantinya dengan pemikiran bebas (ijtihâd) yang kritis, revolusioner, dan agresif. Semua ini dapat dicapai melalui gerakan pembaruan agama yang akan menyaring dan menyuling cadangan energi yang besar dalam masyarakat, dan akan mencerahkan zaman itu serta membangunkan generasi masa kini. Karena itulah, Syariati berharap, agar orang yang tercerahkan mencapai kesadaran diri yang progresif. ${ }^{22}$

Syariati menolak dominasi politik kaum ulama. Sebaliknya, ia menempatkan kaum "intelektual yang tercerahkan" (rausyan fiker), sebagai pemegang otoritas kekuasaan politik. Orang-orang yang tercerahkan (rausanfiker) itu, kata Syariati, mempunyai tanggungjwab

${ }^{21}$ Lihat Ali Syariati, Man and Islam dalam http://www.shariati.com, diakses tanggal 11 Maret 2015

22 Ibid. 
yang besar yaitu mencari sebab-sebab yang sesungguhnya dari keterbelakangan masyarakatnya dan menemukan penyebab sebenarnya dari kemandegan dan kebobrokan rakyat dalam lingkungannya.

Menurut Syariati, peran rausanfiker dalam perubahan masyarakat sebangun dengan apa yang pernah dibayangkan oleh Antonio Gramsci tentang intelektual organik. Gramsci memetakan potensi intelektual menjadi dua kategori, yaitu itelektual tradisional dan intelektual organik. Intelektual tradisional berkutat pada persoalan yang bersifat otonom dan digerakkan oleh proses produksi. Sebaliknya, intelektual organik adalah mereka yang memiliki kemampuan sebagai organisator politik yang menyadari identitas dari yang diwakili dan mewakili. ${ }^{23}$ Intelektual organik itu, menurut Gramsci, tidak harus mereka yang fasih berbicara dan berpenampilan seorang intelektual, tetapi lebih dari itu, mereka yang aktif berpartisipasi dalam kehidupan praktis sebagai pembangun, organisator, penasehat tetap, namun juga unggul dalam semangat matematis yang abstrak. ${ }^{24}$

Bagi Syariati, rausanfikr adalah kunci pemikirannya karena tidak ada harapan untuk perubahan tanpa peran mereka. Mereka adalah agen perubahan sosial yang nyata, karena pilihan jalan mereka adalah meninggalkan menara gading intelektualisme dan turun untuk terlibat dalam problem-problem riil masyarakat. Mereka adalah katalis yang meradikalisasi massa yang sedang tidur panjang menuju revolusi melawan penindas. Masyarakat dapat mencapai lompatan kreativitas menuju perubahan fundamental struktur sosial-politik atas peran katalis rausanfikr.

Dari seluruh bangunan pemikiran Syariati tentang Islam dan revolusi di atas, sumbangan terbesarnya sebenarnya bukan dalam kekuatannya sebagai seorang teoretikus Islam di bidang ilmu-ilmu sosial, seperti Ibn Khaldûn dengan Muqaddimah-nya, atau barangkali seperti Erward Said yang dengan buku Orientalism yang telah membongkar dan meruntuhkan bangunan ilmu-ilmu sosial "Barat" yang selama ini dibangun di atas kekuasaan dalam era kolonialisme. Sumbangannya yang paling monumental adalah tesisnya yang

23 Roger Simon, Gagasan-gagasan Politik Gramsci, terj. Kamdani dan Imam Bahaqi (Yogyakarta: Pustaka Pelajar dan Insist, 1999), 142-145.

${ }^{24}$ Made Pramono, "Melacak Basis Epitemologi Antonio Gramsci", dalam Listiyono Santoso (ed.), Epitemologi Kiri: Seri Pemikiran Tokoh (Yogyakarta: Ar-Ruzz, 2003), 85. 
menyatakan bahwa "kesadaran kolektif" yang menjadi basis kekuatan revolusioner tidak selalu berangkat dari kesadaran kelas, tetapi juga bisa dari kesadaran agama.

\section{Ḥasan Hanafí: Transformulasi Teologi dan Merawat Nalar Kritis}

Hasan Hanafi, intelektual Mesir yang dikenal dengan proyek pemikiran kiri Islam. Kiri Islam (al-Yasâr al-Islâmî) bukan Islam berbaju Marxisme karena itu berarti menafikan makna revolusioner dalam Islam sendiri. ${ }^{25}$ Kiri Islam lahir dari kesadaran penuh atas posisi tertindas umat Islam, untuk kemudian melakukan rekonstruksi terhadap seluruh bangunan pemikiran Islam tradisional agar dapat berfungsi sebagai kekuatan pembebasan.

Hanafi banyak menyerap dan mengonsentrasikan diri pada kajian pemikir Barat pramodern dan modern. Karena itu, Kazuo Shimogaki mengategorikan Hanafî sebagai seorang modernis-liberal karena ideide liberalisme Barat, demokrasi, rasionalisme, dan pencerahan telah banyak mempengaruhinya. Banyak hal yang oleh Hanafî diklaim telah "stagnan" dan dicarikan ruh yang baru. Salah satunya adalah tentang teologi tradisional, bahwa teologi bukanlah ilmu murni yang hadir dari kehampaan sejarah, melainkan merefleksikan konflik-konflik sosial politik. Oleh karena itu, kritik kepada teologi menjadi keniscayaan. "Teologi bukan ilmu tentang Tuhan (seperti arti secara epistemologi dari kata theose dan logos), melainkan ilmu tentang kata (kalâm) Tuhan, karena Tuhan tidak tunduk kepada ilmu. Tuhan mengungkapkan diri dalam firman-Nya yang berupa wahyu. ${ }^{26}$

${ }^{25}$ M. Ridlwan Hambali, "Hasan Hanafi: Dari Islam Kiri, Revitalisasi Turats, hingga Oksidentalisme", dalam. M. Aunul Abied Shah (ed.), Islam Garda Depan: Mosaik Pemikiran Islam Timur Tengah (Bandung: Mizan, 2001), 225. Hanafî menjelaskan: "Kiri adalah konsep ilmu sosial. Kiri adalah kekuatan untuk berubah. Revolusi Islam, keadilan Islam, jihad Islam, semua itu konsep Kiri Islam. Kiri Islam tidak ada pengaruh dari Marxisme atau Sosialisme, karena pemikiran saya dilatarbelakangi keadaan sosial di negara-negara Islam yang mayoritas masih didominasi kemiskinan dan angka pengangguran yang tinggi, misalnya Indonesia. Kita tidak perlu menjadi seorang Marxis untuk dapat melihat bahwa persoalan keadilan sosial di sini. Mengapa orang yang berbicara tentang keadilan sosial harus seorang Marxis?”. Diambil dari wawancara dengan Hasan Hanafi yang dimuat Majalab Tempo, (No. 14/XXX/4-11 Juni 2001).

${ }^{26}$ Hasan Baharun, Metodologi Studi Islam Percikan Pemikiran Tokoh dalam Membumikan Agama (Yogyakarta: Ar-Ruzz Media, 2011), 16. 
Hanafî mengingatkan kita atas kondisi zaman sekarang yang telah berubah, dan bahwa setiap pemikiran dan aliran yang pernah ada selalu mengikuti kondisi dan tuntutan zamannya. Karena itu, zaman sekarang sangat menuntut lahirnya pemikiran baru yang sanggup menampilkan akidah Islam dalam menghadapi segala problematika Muslim. Problematika yang berbentuk keterbelakangan dan imperialisme dalam segala bentuk dan ragamnya. Dengan begitu, akidah Islam dapat menjadi pemacu kemajuan dalam mengentaskan keterbelakangan, menghapus penjajahan, merealisir keadilan sosial, dan mempersatukan umat dari perpecahan barisan mereka. Dengan demikian, ilmu tauhid menjadi ilmu kebangkitan kaum Muslim, dan akidah Islam menjadi ideologi revolusi bagi rakyat Muslim. ${ }^{27}$

Menurut Hanafî, apa yang dimaksud tauhid bukan merupakan sifat dari sebuah dhât (Tuhan), diskrepsi ataupun sekadar konsep kosong yang hanya ada dalam angan belaka, tetapi lebih mengarah untuk sebuah tindakan konkret $(f i l)$, baik dari sisi penafian maupun penetapan (ithbât). Sebab apa yang dikehendaki dari konsep tauhid tersebut tidak akan bisa dimengerti dan dipahami kecuali dengan ditampakkan. Jelasnya, konsep tauhid tidak bermakna tanpa direalisir dalam kehidupan konkret.

Realisasi nafy (pengingkaran) adalah dengan menghilangkan tuhantuhan modern, seperti ideologi, gagasan, budaya, dan ilmu pengetahuan yang membuat manusia sangat tergantung kepadanya dan menjadi terkotak-kotak sesuai dengan ideologi dan ilmu pengetahuan yang dimiliki dan dipujanya. Realisasi dari ithbât (penetapan) adalah dengan penetapan satu ideologi yang menyatukan dan membebaskan manusia dari belenggu tuhan-tuhan modern tersebut.

Dengan demikian, dalam konteks kemanusiaan yang lebih konkret, tauhid adalah upaya pada kesatuan sosial masyarakat tanpa kelas. Distingsi kelas bertentangan dengan kesatuan dan persamaan eksistensi manusia. Tauhid berarti kesatuan kemanusiaan tanpa diskriminasi ras, perbedaan ekonomi, perbedaan masyarakat maju dan berkembang, Barat dan bukan Barat, dan seterusnya. ${ }^{28}$

27 Badruzaman, Kiri Islam Hasan Hanafi Menggugat Kemapanan Agama dan Politik (Yogyakarta: Tiara Wacana, 2005), 122-127.

28 A. Khudori Soleh, Wacana Baru Filsafat Islam (Yogyakarta: Pustaka Pelajar, 2004), 47-49. 
Perubahan orientasi dan paradigma teologi tersebut sebenarnya mempunyai landasan yang cukup kokoh dalam Islam. Secara normatif, kita menegenal ajaran sufistik yang menjadi rujukan pendefinisian diri manusia, yaitu: man 'araf nafsah 'araf rabbah (seseorang yang mengetahui dirinya, akan mengetahui Tuhannya). Ajaran ini memposisikan manusia sebagai subjek sekaligus objek dalam memahami diri dan Tuhan. Sebagai subjek, manusia dituntut arif memahami dirinya dalam kapasitasnya sebagai manusia yang mempunyai kelebihan dan kekurangan tanpa melibatkan atribut apaun di luar diri. Ajaran tersebut menunjukkan betapa manusia yang fisis lebih menyatu dengan Tuhan yang non-fisis, atau paling tidak ada unsur-unsur Tuhan (sifat nâsût Tuhan) yang menyatu dalam diri manusia (sifat lâhût manusia). Karenanya, ketika manusia berpikir tentang dirinya, pada dasarnya ia telah berpikir tentang Tuhan; manusia yang melakukan pembelaan terhadap hak dan nilai-nilai kemanusiaan pada dasarnya ia telah melakukan pembelaan terhadap hak-hak dan nilai-nilai ketuhanan. ${ }^{29}$

Perubahan paradigma tersebut menyangkut beberapa hal, antara lain: pertama, merubah paradigma teologi dari teosentris menjadi lebih antroposentris. Jika paradigma teosentris melihat urusan dunia sebagai urusan Tuhan, maka paradigma antroposentris melihat urusan dunia sebagai urusan manusia. Kedua, mengubah kaca pandang terhadap dunia sebagai segala sesuatu yang menyatu dengan Tuhan, sehingga ia selalu didekati dengan perspektif ketuhanaan menjadi teologi yang melihat dunia sebagai sesuatu yang terpisah dengan Tuhan. Karena itu, dunia dipandang dengan perspektif "dunia", hingga dunia tidak selalu didekati dengan perspektif ilahi, meskipun yang bersifat ilahi tidak dapat ditolak sama sekali. Ketiga, mengubah cara pandang terhadap alam sebagai "tanda" kehadiran Tuhan menjadi tanda atau instrumen untuk menyembah Tuhan. Keempat, menggeser cara pandang teologi yang menjadikan individu sebagai fokus dan titik tolak dalam memandang kenyataan hidup. Konsekuensi dari hal ini, konsep kesalehan dengan sendirinya menjadi berubah; dari kesalehan ritual individual menjadi kesalehan sosial. ${ }^{30}$

Counter pemikiran yang menganggap agama sebagai cara orang bertuhan saja (teosentris) melahirkan tafsir dan cara pandang

\footnotetext{
${ }^{29}$ Rumadi, Masyarakat Post Teologi: Wajah Baru Agama dan Demokrasi Indonesia (Bekasi: Gugus Press, 2002), 22.

${ }^{30} \mathrm{Ibid}$.
} 
sebaliknya, yaitu agama adalah cara orang untuk bermanusia. Cara pemahaman agama seperti ini melahirkan teologi antroposentris. Suatu teologi yang menempatkan manusia sebagai pusat segalanya. Tuhan telah menciptakan alam semesta. Karena itu manusia bebas untuk menentukan, sebab substansi agama adalah cara memanusiakan dan menyejahterakan manusia.

Harus diakui, tradisi teologi Sunnî tidak mempunyai perangkat sosial untuk menjawab berbagai problematika kemasyarakatan, tidak mampu bergulat dalam belantara “anarki pemaknaan”, gagap mengakomodir derasnya dinamika sosisal, dan rapuh untuk menjadi pijakan bagi pemberdayaan masyarakat yang lebih berorientasi sosial, kemanusiaan dan kerakyatan. Kritik semacam ini bukan hal yang mengada-ada, tapi merupakan kegelisahan banyak orang yang menyadari pentingnya teologi dalam proses transformasi dan pemberdayaan rakyat, sesuatu yang tak ditemukan dalam teologi konvensional. Kajian-kajian teologi Sunnî yang melangit dan hampirhampir tidak ada kaitannya dengan rakyat. Tema-tema yang diangkat dalam teologi konvensional ini selalu saja berbicara pada "aras atas" seperti Tuhan, malaikat, langit, akhirat, surga, kitab suci dan seterusnya. Sedangkan tema-tema yang berkaitan dengan "aras bawah" seperti manusia, rakyat, dunia, bumi dan seterusnya hampirhampir tidak mendapatkan porsi. ${ }^{31}$

Untuk mengatasi kekurangan teologi klasik yang dianggap tidak berkaitan dengan realitas sosial, Hanafî menawarkan dua teori. ${ }^{32}$ Pertama, analisa bahasa. Bahasa dan istilah-istilah dalam teologi klasik adalah warisan nenek moyang dalam bidang teologi yang khas yang seolah-olah sudah menjadi doktrin yang tidak bisa diganggu gugat. Menurutnya, istilah-istilah dalam teologi sebenarnya tidak mengarah pada yang transenden dan gaib, tetapi juga mengungkap tentang sifatsifat dan metode keilmuan, yang empiris-rasional seperti iman, amal dan imâmah, yang historis seperti nubuwwah dan adapula yang metafisik, seperti Tuhan dan akhirat. Kedua, analisa realitas. Menurut Hanafi, analisa ini dilakukan untuk mengetahui latar belakang historissosiologis munculnya teologi dari masa lalu dan bagaimana pengaruhnya bagi kehidupan masyarakat atau penganutnya. Selanjutnya, analisa realitas berguna untuk menentukan stressing bagi arah dan orientasi teologi kontemporer.

${ }^{31}$ Rumadi, Masyarakat Post Teologi, 13.

${ }^{32}$ Ridwan, Reformasi, 50-51. 
Untuk melandingkan dua usulannya tersebut, Hanafî paling tidak menggunakan empat metode berpikir: ${ }^{33}$

1. Dialektika

Dialektika $^{34}$ adalah metode pemikiran yang didasarkan atas asumsi bahwa perkembangan proses sejarah terjadi lewat konfrontasi dialektis di mana tesis melahirkan antitesis kemudian melahirkan sintesis. Hanafî menggunakan metode ini ketika sebelumnya menjelaskan tentang sejarah perkembangan pemikiran Islam dan untuk menentukan titik pijak dan alasan dasar mengadakan suatu revolusi. Revolusi dipandang sebagai panggilan sejarah. Hanafî juga menggunakan dialektika untuk menggagas teologi sebagai antropologi yang merupakan cara "ilmiah" untuk mengatasi keterasingan teologi itu sendiri. ${ }^{35}$ Hanafî berusaha membumikan kalam yang dianggap melangit.

\section{Hermeneutika}

Hermeneutika $^{36}$ tidak hanya menjelaskan teks dan berusaha menyelami kandungan makna literalnya. Lebih dari itu, hermeneutika berusaha menggali makna dengan memperhatikan horizon-horizon yang melingkupi teks tersebut. Horizon yang dimaksud adalah horizon teks, horizon pengarang dan horizon pembaca. ${ }^{37}$

Hanafî menggunakan metode hermeneutika untuk melancarkan gagasannya berupa teologi antroposentris, dari wahyu kepada kenyataan, dari logos sampai praktis, dari pikiran Tuhan sampai manusia. Apa yang dimaksud hermeneutika, bagi Hanafî, bukan sekadar ilmu interpretasi tetapi juga ilmu yang menjelaskan tentang

\footnotetext{
${ }^{33}$ Ibid., 18.

34 Kata dialektika berasal dari bahasa Yunani dialektos yang berarti pidato, pembicaraan, perdebatan, seni atau ilmu dialektika berawal dari penarikan pembedaan-pembedaan yang ketat. Dialektika kiranya dimulai oleh Zero, Socrates dan Plato. Peranan dialektika, interpretasi mengenai hakikatnya dan penghargaan atas kegunaaanya sangat bervariasi sepanjang sejarah filsafat. Itu dikarenakan perdebatan posisi atau pendapat setiap filsuf. Lihat Lorens Bagus, Kamus Filsafat (Jakarta: Gramedia, 2000), 116.

35 A. H. Ridwan, Reformasi Intelektual Islam Pemikiran Hassan Hanafi tentang Reaktualisasi Tradsisi Keilmuan Islam (Jakarta: Ittaqo Press, 1998), 18.

36 Hermeneutika berarti Ilmu dan teori tentang penafsiran yang bertujuan menjelaskan teks mulai dari ciri-cirinya, baik objektif (maksud pengarang). Lihat Bagus, Kamus Filsafat, 285.

37 Fakhruddin Faiz, Hermeunetika Qur'ani: Antara Teks, Konteks, dan Kontekstualisasi (Yogyakarta: Qalam, 2002), 11.
} 
pikiran Tuhan kepada tingkat dunia, dari yang sakral menjadi realitas sosial.

\section{Fenomenologi}

Hanafî mengetahui pentingnya menggunakan metode fenomenologi ${ }^{38}$ sebagai pilihan metodologi yang tepat sebagaimana dijelaskannya: "sebagai gerakan dari gerakan Islam di Mesir, dan sebagai seorang fenomenolog, saya tidak mempunyai pilihan lain untuk tidak menggunakan metodologi fenomenologi dalam menganalisis Islam alternatif di Mesir. Dengan metode ini Hanafî bercita-cita agar realitas dunia Islam dapat berbicara bagi dirinya sendiri". 39

Hanafî tidak percaya pada anggapan ada teks objektif, karena hubungan antara teks (al-maqri) sebagai fenomena dan interpreuter (al-qâri') sebagai subjek sangat ditentukan oleh intensionalitas (al-qașd) pembaca. Fenomenologi yang sering dikategorikan sebagi idealisme tetapi sangat menekankan kesadaran subjek untuk melihat kenyataan secara langsung (tanz̧îr al-mubâshir li al-waqî́) ini mempermudah Hanafî untuk menjelaskan kehebatan sejarah Islam. Meminjam kerangka idealisme fenomenologi Edmund Husserl inilah Hanafi mengumandangkan Filsafat revolusioner Islam, terutama pemikiran Jamâl al-Dîn al-Afghânî dan Sayyid Quṭb. ${ }^{40}$

4. Metode Eklektik

Metode eklektik ${ }^{41}$ dipakai oleh Ḥanafî untuk membangun pemikirannya (reaktualisasi), dengan cara memilih-milih pemikiran suatu mazhab. Dalam konteks ini, untuk membangun teologi yang lebih antroposentris, Hanafî merepresentasikan rasionalisme

\footnotetext{
${ }^{38}$ Fenomenologi merupakan sebuah pendekatan filsafat yang berpusat pada analisis terhadap gejala yang membanjiri kesadaran manusia. Sedang arti sempitnya adalah ilmu tentang gejala yang menampakkan diri pada kesadaran kita. Bagus, Kamus Filsafat, 234.

${ }^{39}$ Ridwan, Reformasi, 32

40 Hassan Hanafi, Tafsir Fenomenologi, terj. Yudian Wahyudi Asmin (Yogyakarta: Bismillah Press, 2001), iii.

${ }^{41}$ Eklektif dalam bahasa Inggris eclectism berasal dari bahasa Yunani $e k$ (keluar) dan tego (pilih, pilah). Eklektik yang berasal dari kata Yunani yaitu eklektikos, yang bermakna seseorang yang memilih, dan dari eklegein berarti mengambil, memilih dari. Salah satu pengertian dari eklektic adalah memilih gagasan atau ide-ide (konsep kepercayaan, doktrin) dari berbagai sistem pemikiran dalam proses menyusun dan mengembangkan sistem pemikiran sendiri. Lihat Bagus, Kamus Filsafat, 181-182.
} 
Mu'tazilah. Mu'tazilah dipandang Hanafî sebagi refleksi gerakan rasionalisme, naturalisme, kebebasan manusia dan demokrasi. ${ }^{42}$

Kepentingan rekonstruksi itu untuk menjadikan teologi tidak sekadar sebagai dogma keagamaan kosong, melainkan ia menjelma sebagai ilmu tentang perjuangan sosial, menjadikan keimanan keimanan berfungsi secara aktual sebagai landasan etis dan motivasi tindakan manusia. Karena itu, gagasan-gagasan Hanafí yang berkaitan dengan teologi berusaha untuk mentransformulasikan teologi tradisional yang bersifat teosentris menuju antroposentris, dari Tuhan kepada manusia (bumi), dan dari pemahaman tekstual kepada pemahaman yang kontekstual, dari teori kepada tindakan dan dari takdir menuju kehendak bebas. ${ }^{43}$

Menurut Hanafî, pemikiran ini minimal didasarkan atas dua alasan: Pertama, kebutuhan akan adanya sebuah ideologi yang jelas di tengah pertarungan global antara berbagai ideologi. Kedua, pentingnya teologi baru yang bukan hanya bersifat teoretik tetapi sekaligus juga praktis yang bisa mewujudkan sebuah gerakan dalam sejarah. ${ }^{44}$

Islam mengimplikasikan pembebasan manusia dari segala bentuk penindasan, eksploitasi, serta ketakadilan dan kesewenang-wenangan. Karenanya, memahami Islam harus dengan melihat determinisme sejarahnya agar tidak terjebak kepada pemahaman yang parsial. Istilah ibadah, yakni ibadah mạdah dan sosial, dapat dijalankan secara seimbang; sebuah idealitas bagi personifikasi seorang Muslim sejati. Watak egaliter Islam—sebagai manifestasi agama pembebasan-harus digunakan dalam memahami konsepsi manusia dan realitas.

Menjadi seorang Muslim sejati tentu harus memperhatikan aspek peran manusia di bumi. Dengan demikian, seorang Muslim tidak akan terlepas dari hakikat sebagai manusia yang harus beribadah kepada Tuhannya dan menjalankan fungsi sosial dan tidak terjebak (hanya mengoptimalkan) pada salah satu dari keduanya, yakni ekstremisme ritual $^{45}$ maupun ekstremisme sosial. ${ }^{46}$

Dengan analisis imperaktif, revolusi dipandang perlu dalam kerangka kebutuhan masyarakat yang sedang berkembang di dunia

\footnotetext{
${ }^{42}$ Shimogaki, Kiri Islam, 95-96.

${ }^{43}$ Ridwan, Reformasi, 50.

${ }^{44}$ Ibid., 50.

${ }^{45}$ Perhatian yang cukup kuat terhadap ibadah ritual dan menyampingkan ibadah sosial.

46 Perhatian yang kuat terhadap ibadah sosial dengan meninggalkan ritual, yang pada akhirnya aktivitas sosial tanpa muatan spiritual.
} 
modern. Sejalan dengan perkembangannya, struktur teologi yang diwariskan merefleksikan struktur kekuasaan umum di dalam masyarakat Muslim dan mendukung yang kuat melawan yang lemah. Dalam konteks ini, aspirasi massa perlu dibela dengan cara mendidik mereka dalam sistem oposisi. Oposisi yang ditawarkan adalah oposisi yang datang secara terbuka dari dalam. Oposisi ini bergerak secara resmi dengan munggunakan jalur keamanan seperti ceramah, memerintahkan kebaikan dan melarang kejahatan, memiliki jalan lain dalam pengadilan melawan kekuasaan politik tertinggi dalam negara; suatu rancangan revolusioner Islam yang dapat disepakati melalui konsensus komunitas, yang mengatasi perbedaan di dalam kerangka teoretis dan sistem kepercayaan doktrinal guna membantu semua masyarakat tradisional berubah dari dogma ke revolusi. ${ }^{47}$

\section{Revitalisasi Islam Autentik}

Pemikiran Syariati dan Hanafî merupakan pencarian tentang keautentikan Islam, karena mereka berdua beranggapan bahwa ia belum menemukan Islam yang sesungguhnya, yaitu Islam yang bisa membawa umat kepada kesejahteraan hidup baik dalam bidang sosial, politik dan ekonomi juga dalam bidang spritualitas.

Menurut keduanya, pelajaran utama yang dibawa oleh Nabi adalah manusia sebagai individu yang diilhami Tuhan untuk dapat membebaskan nasib mereka sendiri dari kungkungan alam, sejarah, masyarakat dan diri pribadi. Kebangkitan mistis membuka jalan bagi rekonstruksi sukarela (istilah Muhammad Iqbal) atas diri dan masyarakat. Seperti dinyatakan Quṭb, ${ }^{48}$ Islam menyeru kepada pemeluknya untuk melakukan jihad untuk mencapai tujuan ini, tujuan manusia. Kaum Muslim melakukan jihad atas nama Tuhan untuk membentuk kepribadian dan sejarah mereka sendiri dan membebaskan diri dari konsep agama, konsep sejarah dan konsep diri yang telah memenjarakan mereka.

Ideologi membentuk kembali kebudayaan dan peradaban. Ia lahir dari keunikan kesadaran manusia yang muncul dalam kondisi sosial konkret. Ideologi akan berperan efektif jika ia menyuarakan kebutuhan dan aspirasi masyarakat bersangkutan. Tiap mazhab yang tidak berdasarkan diri pada landasan masyarakatnya adalah layaknya

\footnotetext{
${ }^{47}$ John L. Esposito dan John O. Voll, Tokoh Kunci Gerakan Islam Kontemporer, terj. Sugeng Haryanto, dkk. (Jakarta: Raja Grafindo Persada, 2002), 92.

48 Robert D. Lee, Mencari Islam Autentik: Dari Nalar Puitis Iqbal bingga Nalar Kritis Arkoun, terj. Ahmad Baiquni (Bandung: Mizan, 2000), 104-107.
} 
buku bagus di perpustakaan yang hanya dibaca oleh segelintir mahasiswa dan profesor. Jika seorang pemikir bebas memisahkan diri dari masyarakatnya, kemanapun ia pergi dan apapun yang ia kerjakan, masyarakatnya berada dalam kebobrokan. Para Nabi mencapai keberhasilan karena mereka muncul dari massa dan berbicara dengan bahasa yang dapat dimengerti khalayak mereka membangun klaimklaim universal, akan tetapi keberhasilan mereka dalam membangun lagu kebudayaan berakar dari pemahaman mereka tentang keadaan tempat mereka hidup dan berjuang. Seberapapun tinggi tingkat kebenaran klaim mereka, namun pernyataan yang sahih yang diekspresikan pada ruang dan waktu yang tidak tepat pastilah sia-sia belaka.

Pemikiran Syariati dan Hanafî memiliki signifikansi sangat besar bagi perubahan umat Islam, pemikirannya sangat berpengaruh terhadap perubahan sosial di negara-negara yang berpenduduk Muslim. Gagasannya tidak hanya menggema di Iran dan Mesir, tetapi menjalar ke seluruh dunia yang masih begitu sangat percaya kepada janji-janji kapitalisme. Keduanya membangkitkan kesadaran kritis manusia modern bahwa melawan tirani harus dimulai dari paradigma berpikir yang lurus, oleh karenanya Syariati dan Hanafî menggagas tentang revolusi berbasis Islam sebagai agama pembebasan.

Dalam konteks kekinian, Indonesia setidaknya mengalami lima problem dasar bangsa yakni, Pertama, moralitas. Indonesia mengalami krisis moralitas yang sangat krusial, elemen-elemen penting politik seperti eksekutif, legislatif dan yudikatif gagal membangun negara. Negara bagai perahu pecah yang kehilangan kendali karena para pemimpinnya mengalami krisis moralitas. Para pemimpin Indonesia tidak menjadi teladan baik, sebaliknya menjadi contoh yang buruk. Kedua, kebebasan. Masyarakat Indonesia mengalami euforia kebebasan yakni spirit menikmati kebebasan tanpa memahami batasan kebebasan itu sendiri, sehingga terjadi pengerusakan fasilitas publik atas nama kebebasan. Ketiga, kemanusiaan. Masyarakat Indonesia mengalami krisis kemanusiaan yang ditandai dengan kemiskinan dan fenomena pengusiran warga dari tanah kelahirannya. Keempat, keadilan sosial. Masalah keadilan sosial di Indonesia adalah masalah krusial karena tidak adanya kemauan dari elite politik untuk mewujudkan keadilan sosial. Keadilan sosial hanya menjadi mimpi yang tidak pernah mewujud. Kelima, perdamaian antarmanusia, golongan masyarakat dan negara. Beberapa tahun terakhir, Indonesia sering terjadi konflik 
agama, suku dan kelompok. Segala macam konflik ini mengganggu stabilitas nasional dalam pembangunan.

Lima problem besar bangsa tersebut tidaklah cukup untuk direnungkan saja, melainkan diperlukan untuk bergerak melakukan perubahan. Semangat perubahan inilah yang kemudian ditemukan basis legitimasi spiritualnya dengan gagasan-gagasan Syariati dan Hanafî melalui Islam yang progresif, manusia yang eksistensial dan intelektual yang tercerahkan. Secara universal, seluruh aspek kehidupan sosial Islam harus diintegrasikan dalam "jaringan relasional Islam”. Jaringan ini diderivasikan dari pandangan dunia tauhid, yang mencakup aspek keagamaan dan keduniawian, spiritual dan material, individual dan sosial. Jaringan relasional Islam ini akhirnya teruji dalam bentuk praksis ibadah ritual yang merupakan kewajiban yang mesti dijalankan oleh umat Islam. Selain itu, perlu digagas relasi tauhid dan pembebasan serta implementasinya, kemudian masyarakat seperti apa yang diinginkan dalam konteks tauhid.

Menjadikan tauhid sebagai spirit perubahan sosial menuntut keberagamaan Muslim yang tidak hanya sekadar ritual kering dengan aksi sosial kesadaran diri, kemanan bebas, dan kreativitas. Kesadaran diri menuntun manusia untuk memilih, kemampuan memilih menolong manusia untuk mencipta yakni mencipta sesuatu yang bukan alam. Tiga prinsip tersebut saling melengkapi dan saling memerlukan dalam suatu cara yang terpadu. Bersatunya kesadaran diri, kemanan bebas dan kreativitas dalam diri manusia melahirkan jiwa-jiwa pemberontak.

Dengan memperkuat kembali pemaknaan-pemaknaan basis keimanan dengan pendekatan realitas sosial akan mendorong progresivitas umat Islam pada mandat sejatinya yakni keberpihakan pada problem-problem masyarakat mustad'afîn. Revitalisasi tersebut juga menghadirkan wajah keberagamaan Muslim yang tidak ekstrem terhadap ritual maupun sosial dan tentu saja lebih humanis. ${ }^{49}$

Revitalisasi nilai-nilai sosial tauhid memberikan kontribusi besar antara lain melahirkan sikap, Antara lain: pertama, antietnosentrisme, yakni spirit untuk menghilangkan sikap fanatisme buta terhadap suku dan golongan. Antietnosentrisme berpijak kepada moralitas yakni

\footnotetext{
${ }^{49}$ Ide Islam humanis dapat dilacak pada salah satu model pemikiran Jamâl al-Bannâ dalam konsep utama pembaruan pemikiran keagamaannya. Lihat lebih jauh dalam Mukhammad Zamzami, "Teologi Humanis Jamâl al-Bannâ: Sebuah Rekonstruksi Epistemologis Studi Keislaman”, Teosofi: Jurnal Tasawuf dan Pemikiran Islam, Vol. 2, No. 1 (Juni 2012), 174-200.
} 
prinsip-prinsip dasar kemanusiaan yang menjelaskan bahwa manusia sebagai makhluk rasional yang bertanggung jawab atas hidupnya sendiri. Moralitas merupakan kekhususan makhluk rasional. Berkat rasionya, manusia menjadi makhluk yang bermartabat. Pijakan antietnosentrisme berikutnya adalah perdamaian. Perdamaian tidak membiarkan eksploitasi dan permusuhaan antarmanusia. Kedua, universalisme yang bermakna pengakuan terhadap identitas masingmasing etnis dan pengakuan dari masing-masing etnis tentang arti perbedaan. Pijakan utama universalisme ini adalah pengakuan kesetaraan semua manusia. Kesetaraan adalah solidaritas antar-semua warga masyarakat. Ketiga, kemerdekaan. Spirit kemerdekaan ini diarahkan kepada penjaminan kepada masing-masing individu untuk merasa bahagia dengan pilihan hidupnya. Arti kemerdekaan yang sejati adalah spirit kemanusiawian, yakni spirit solidaritas terhadap sesama manusia dan lingkungan. Pijakan kemerdekaan berikutnya adalah keadilan sosial yang menjelaskan bahwa ketaksamarataan dalam hal kekuasaan, kekayaan dan status hanya dapat dibenarkan sejauh semuanya itu sangat menguntungkan anggota masyarakat yang paling terbelakang, apalagi sejauh posisi atau jabatan yang membawa ketidak samarataan dalam hal kekuasaan, kekayaan dan status itu juga benarbenar terbuka bagi semua orang.

\section{Penutup}

Realitas faktual tentang kemiskinan, ketertindasan dan keterbelakangan menjadi ancaman bagi umat Islam. Selama ini gerakan Islam terlalu bersifat normatif dan cenderung mengabaikan adanya difrensiasi, segmentasi dan stratifikasi sosial yang terjadi dalam masyarakat. Sebagai akibatnya, sentimen normatif mengenai persatuan dan kesatuan umat menjadi jauh lebih menonjol daripada komitmennya yang aktual untuk membela kelompok-kelompok yang lemah, tergusur dan tertindas di dalam masyarakat. Konsep-konsep objektif al-Qur'ân mengenai du'afâ' dan mustad'afín yang diartikan sebagai kelompok yang lemah dan tertindas secara ekonomi dan politik hanya dipahami pada tataran konsepnya yang normatif daripada dielaborasi secara empiris.

Diskursus tentang transformasi teologi menuju teologi antroposonteris, ataupun dengan penamaan teologi pembebasan sejatinya adalah kajian-kajian yang telah berkembang di era 90-an. Intelektual Muslim dalam kurun waktu itu mampu mendorong terbukanya interpretasi-interpretasi baru terhadap jaringan relasional 
Islam dengan pendekatan realitas faktual. Ribuan buku diterbitkan dari sarjana-sarjana Muslim dengan corak yang sama yakni nalar kritis atas wacana keagamaan.

Menurut penulis, diskursus-diskursus itu berhenti menjadi wacana-wacana di ruang kedap perguruan tinggi dan tumpukan buku. Hingga kini kita belum melihat intelektual Muslim Indonesia yang tidak hinga kritis dalam berpikir tetapi juga aktif dan progresif hadir di tengah-tengah masyarakat melakukan advokasi, menghapus kesenjangan teoretik dengan realitas faktualnya.

Dengan demikian, apa yang didengungkan oleh Syariati dan Hanafí dengan intelektual tercerahkan seyogianya tidak pernah menjadi isu lama atau gagasan usang. Ia akan terus menjadi tuntutan tidak hanya bagi individu Muslim rasional, tetapi juga institusi-institusi pendidikan untuk mencetak kader-kader Muslim yang tercerahkan, yang tidak tercerabut dari akar tradisinya.

\section{Daftar Rujukan}

Azra, Azyumardi. Pergolakan Politik Islam: Dari Fundamentalisme, Modernisme, hingga Post-Modernisme. Jakarta: Paramadina, 1996.

Badruzaman. Kiri Islam Hasan Hanafi Menggugat Kemapanan Agama dan

Politik. Yogyakarta: Tiara Wacana, 2005.

Bagus, Lorens. Kamus Filsafat. Jakarta: Gramedia, 2000.

Baharun, Hasan. Metodologi Studi Islam Percikan Pemikiran Tokoh dalam

Membumikan Agama. Yogyakarta: Ar-Ruzz Media, 2011.

Bellah, Robert N. dan Hammond, Phillip E. Varieties of Civil Religion:

Beragam Bentuk. Agama Sipil dalam Beragam Bentuk Kekuasaan Politik,

Kultural, Ekonomi, dan Soaial, terj. Imam Khoiri. Yogyakarta: Ircisod, 2003.

Esposito, John L. dan Voll, John. O. Tokoh Kunci Gerakan Islam

Kontemporer, terj. Sugeng Haryanto, dkk. Jakarta: Raja Grafindo Persada, 2002.

Faiz, Fakhruddin. Hermeunetika Qur'ani: Antara Teks, Konteks, dan Kontekstualisasi. Yogyakarta: Qalam, 2002.

Hambali, M. Ridlwan. "Hasan Hanafi: Dari Islam Kiri, Revitalisasi

Turats, hingga Oksidentalisme", dalam. M. Aunul Abied Shah (ed.), Islam Garda Depan: Mosaik Pemikiran Islam Timur Tengah. Bandung: Mizan, 2001.

Hanafi, Hassan. Tafsir Fenomenologi, terj. Yudian Wahyudi Asmin.

Yogyakarta: Bismillah Press, 2001.

Ishomudin. Pengantar Sosiologi. Jakarta: Ghalia Indonesia, 2002. 
Lee, Robert D. Mencari Islam Autentik: Dari Nalar Puitis Iqbal hingga Nalar Kritis Arkoun, terj. Ahmad Baiquni. Bandung: Mizan, 2000.

Magnis-Suseno, Franz. Pemikiran Karl Marx: Dari Sosialisme Utopis ke Perselisihan Revisionisme. Jakarta: Gramedia Pustaka Utama, 2000.

Pramono, Made. "Melacak Basis Epitemologi Antonio Gramsci", dalam Listiyono Santoso (ed.), Epitemologi Kiri: Seri Pemikiran Tokoh. Yogyakarta: Ar-Ruzz, 2003.

Rais, M. Amin. Cakrawala Islam: Antara Cita dan Fakta. Bandung: Mizan, 1997.

Ridwan, A. H. Reformasi Intelektual Islam Pemikiran Hassan Hanafi tentang Reaktualisasi Tradsisi Keilmuan Islam. Jakarta: Ittaqo Press, 1998.

Romli, Asep Syamsul M. Isu-isu Dunia Islam. Yogyakarta: Dinamika, 1996.

Rumadi. Masyarakat Post Teologi: Wajah Baru Agama dan Demokrasi Indonesia. Bekasi: Gugus Press, 2002.

Shiddiqi, Nourouzzaman. Jeram-jeram Perdaban Islam. Yogyakarta: Pustaka Pelajar, 1996.

Simon, Roger. Gagasan-gagasan Politik Gramsci, terj. Kamdani dan Imam Bahaqi. Yogyakarta: Pustaka Pelajar dan Insist, 1999.

Soleh, A. Khudori. Wacana Baru Filsafat Islam. Yogyakarta: Pustaka Pelajar, 2004.

Sutrisno, Mudji. "Revolusi Akal Sehat" dalam Frans M. Parera dan T. Jakob Koekerits (eds.), Masyarakat Versus Negara: Paradigma Baru Membatasi Dominasi Negara. Jakarta: Kompas, 2002.

Syari'ati, Ali. Ideologi Kaum Intelektual: Suatu Wawasan Islam, terj. Syafiq Basri dan Haidar Bagir. Bandung: Mizan, 1994.

-----. Makna Haji. Jakarta: Yayasan Fatimah, 2002.

-----. On the Sociology of Islam. Bandung: Mizan Press, 1979.

-----. Tugas Cendekiawan Muslim, terj. M. Amien Rais. Jakarta: Srigunting, Cet. 2, 2001.

Tibi, Bassam. Islam, Kebudayaan dan Perubahan Sosial, terj. Misbah ZE dan Zainul Abbas. Yogyakarta: Tiara Wacana, 1999.

Toynbee, Arnold dan Ikeda, Daesaku. Perjuangkan Hidup: Sebuah Dialog, terj. Iskandar. Jakarta: PT. Internusa, 1987.

Zamzami, Mukhammad. "Teologi Humanis Jamâl al-Bannâ: Sebuah Rekonstruksi Epistemologis Studi Keislaman”, Teosofi: Jurnal Tasawuf dan Pemikiran Islam, Vol. 2, No. 1, Juni 2012. 